\title{
Projecting Democracy: The Formation of Citizenship Across Youth Networks in Brazil*
}

\section{ANN MISCHE}

In August 1992 Brazil was swept by a series of protest demonstrations to demand the impeachment on corruption charges of the country's first elected president in thirty years. The principal protagonists of the rallies were high school and college students who turned out in massive numbers for exuberant, hastily organized marches that closed down the principal avenues of Brazil's major cities. The rallies joined heterogeneous sectors of young people, many with no prior experience of political activism, who became known as the caras pintadas (painted faces) for the improvised, carnavelesque gesture of painting their faces with the colors of the Brazilian fiag. In the words of Lindberg Farias, president of the National Union of Students (UNE), "Our faces were diverse. From those wearing Che Guevara T-shirts to the frequenters of shopping centers. Student researchers on scholarships, together with heavy metal fans and skateboarders".

Despite nostalgic comparisons with the radical student opposition to the dictatorship in the 1960s, this colorful array of young demonstrators gave the 1992 rallies a very different character from the earlier student movement. Amidst Brazil's new political pluralism, the student identity that had galvanized the 1960s no longer had the same unifying force; instead, differences were now bridged by the more expansive language of democratic citizenship. As Lindberg Farias declared, "today the student movement is different [...] It has changed because of the students themselves. They woke up and began to discover what it is to truly fight for citizenship. This is a generation that has consciousness of citizenship."

Beyond the heroics of this affirmation, the very heterogeneity of the 1992 movement raises a series of critical questions about the formation of citizenship in democratizing countries. How, in fact, does a cohort of young people acquire "consciousness of citizenship"? What does "being a citizen" imply in the midst of a period of democratic restructuring,

* I would like to acknowledge the helpful comments received on earlier versions of this paper from José Casanova, Mustafa Emirbayer, Jeff Goodwin, Ira Katznelson, Salvador Sandoval, Charles Tilly and Harrison White, as well as members of the Proseminar of Political Mobilization and Conflict at the New School for Social Research and the Networks Workshop of the Center for the Social Sciences at Columbia University. This research was conducted with funding from the Fulbright-Hayes Doctoral Dissertation Research Abroad Program, the Joint Committee on Latin American and Caribbean Studies of the Social Science Research Council, and the Academy for Educational Development.

International Review of Social History 40, Supplement 3 (1995), pp. 131-158 
in which the meaning and practices of citizenship are less like sturdy, reliable signposts, and more like whizzing political softballs in a conflictual and uncertain transitional game? Does such "consciousness" develop as spontaneously as this example would seem to suggest, or does it involve less visible processes of learning and articulation, which go on behind the scenes of such high public dramas? If so, where does such learning take place, given the increasing diversification of spaces for social and political participation? Not only are networks of study, work and recreation more dispersed than they were for student activists in the $1960 \mathrm{~s}$, but politically motivated youth now have many alternative forms of participation to choose from, including a wide array of political parties, non-governmental groups, social movements, environmental activism, neighborhood associations and cultural activity. What different (and possibly contradictory) meanings does citizenship come to assume in the face of changing networks of civic relationships, among actors with contending projects for the future of Brazil?

In this paper I seek to address such questions by exploring emergence of new forms of civic interaction across networks of Brazilian youth activists who helped to organize the 1992 rallies. In opposition to static and foundationalist approaches that see citizenship as a pregiven set of formal rights and/or cultural values, I argue for a more dynamic conception of citizenship as a multivalent cultural carrier for a diversity of projects of civic intervention, by means of which state and societal actors forge new forms of political relationships. I examine how conceptions of citizenship vary according to the structure and dynamics of the organizational networks in which new projects and relations are formulated and communicated to the wider society.

Such an approach enables us to see that changes in civic relations within democratizing countries are not unidirectional, nor do they conform to pregiven ideals; they cannot be understood by a simple dichotomy between "democratic" and "non-democratic" practices. Instead, young people in different social and political settings invoke a variety of different conceptualizations of citizenship, which in turn support diverse (and sometimes opposing) styles of contestation and alliancemaking within civil society. While the universalizing nature of appeals to citizenship allows heterogeneous actors to bridge political differences, as the pro-impeachment rallies demonstrate, it also allows them to ride with those differences into the political arena, providing the basis for distinct forms of political intervention and challenge.

\section{CITIZENSHIP AND DEMOCRATIC CULTURE IN LATIN AMERICA}

Although a flurry of recent historical studies has focused attention on questions of citizenship and identity-formation (some of which have made strides in conceiving of these in contingent and interactive form), 
few have examined these terms as they are currently employed in the Latin American debate. The bulk of recent work has focused on the link between citizenship and national identity, particularly in relation to political, cultural and legal-juridical debates over national minorities. Yet the use to which citizenship is put during the Latin American transitions has less to do with what Rogers Brubaker, in a recent European study, defines as state-based policies of social closure, ${ }^{1}$ than with societal appeals for political opening - abertura - following the suppression of civil and political participation under authoritarian regimes. In such situations the notion of citizenship comes to mean far more than legal membership in a national-state (with its ensuing rights and privileges); in Brazil, for example, the "national" dimension of civic identity, so important in Europe, is submerged or plays a mainly ceremonious and inclusionary role. Conflicts over national and/or ethnic membership are subordinated to struggles against other forms of social and political exclusion, including state-based repression, corporativist political practices and social/economic marginalization. In the light of these concerns, appeals to citizenship take on multiple social resonances: they function simultaneously as demands for rights and entitlements, calls for autonomy from state repression and control, and moral injunctions for renewed civic participation.

These multiple facets of the discourse of citizenship in countries like Brazil make the process of citizen-formation a complex and ambiguous process. When many of the parents of the caras pintadas were involved in student politics in the 1960 s, the word citizenship had little mobilizing power. The language of social activists in the 1950s and early 1960s centered on "national development" and "modernization", giving way in student circles, as the decade moved from the progressive populism of the Goulart era to the bureaucratic authoritarianism of the military dictatorship, to calls for "liberation" and "revolution". In fact the left in Brazil has traditionally been highly skeptical towards the formal equality of citizenship rights, which emerged in limited fashion in the nineteenth century linked to a "liberalism that was individualist and elitist, tied to the structures of oligarchical privilege", ${ }^{2}$ and subsequently survived in "regulated" fashion under the state corporativism of the Vargas era. ${ }^{3}$ While today's youth were growing up under the dictatorship in the 1970 s, political narratives of participation and/or struggle were suppressed and replaced by those of technocratic expansion; then suddenly, as the military regime gradually loosened its hold, the word

1 Rogers Brubaker, Citizenship and Nationhood in France and Germany (Cambridge and London, 1992).

2 Francisco Weffort, "A Cidadania dos Trabalhadores", in Bolivar Lamounier et al. (eds), Direito, Cidadania e Participacao (São Paulo, 1981), pp. 139-150.

${ }^{3}$ Wanderley Guilherme Dos Santos, Cidadania e Justica: A Politica Social Na Ordem Brasileira (Rio de Janeiro, 1979). 
"citizen" began to appear from all directions. Appeals to citizenship first emerged in the late 1970s in the discourse of striking workers, human rights activists and church-based social movements; throughout the 1980s they were taken up by newly legalized political parties, professional associations and movements of blacks, women and indigenous peoples; and currently during the 1990 s they are permeating the debates of consumer advocates, non-governmental organizations and business leaders.

The multiplicity of recent appeals to citizenship coming from such disparate and conflicting social sectors poses epistemological and empirical challenges to our understanding of civic culture. It raises the need for an analytical distinction between, on the one hand, notions of citizenship as socially constructed and historically variable clusters of claims, narratives and values, and on the other, the particular social relations and projects that such notions support. For the purposes of this paper, I use the term "citizenship" to refer to normative appeals made by social actors based upon variable (and contested) understandings of that term within particular fields of political interaction. In contrast, I use the terms "civic relations", "projects" and "practices" to refer analytically to the structure and dynamics of particular forms of public intervention within such interactive fields.

Such a distinction gives dynamism to the discussion of citizenship by allowing us to examine simultaneously the changing structure of civic relations and the emerging cultural understandings that fuel (and are fueled by) processes of political restructuring. The analytic separation between forms of interaction and their meanings for the actors also allows us to challenge the tensions inherent in two predominant conceptions of citizenship: (1) that which, in the tradition of T.H. Marshall, ${ }^{4}$ stresses the legal basis of citizenship as a set of institutionalized rights - civil, political, social - guaranteed by the state to all members of a polity; and (2) that which, following the classic work of Almond and Verba, focuses on the cultural underpinnings of citizenship as a set of individual attitudes and/or shared values - i.e. solidarity, responsibility, trust, tolerance, etc. - that support participation in democratic institutions. While both rights and values are central to discussions of democratic restructuring in Latin America, such approaches tend to posit the question of citizenship in idealized, tautological (and ultimately self-defeating) terms. Either the lack of universal citizenship rights (and/or the institutional culture to sustain them) is bemoaned as an eternal obstacle to democratic consolidations, or the "rebirth" of civic culture (as if this were something fixed and recognizable) is celebrated as both a diagnosis and prognosis of democratic transitions.

- T.H. Marshall, Citizenship and Social Class (Cambridge, 1950).

s Gabriel Almond and Sidney Verba, The Civic Culture (Princeton, 1963). 
The difficulties posed by such formalistic and/or idealized approaches can be seen in the manner in which questions of rights and values have been interwoven in discussions of the Latin American transitions. Because of their centrality to processes of political reopening, debates over formal citizenship rights are inextricably tied to the question of political culture and democratic values - or as is more often the case, to the alleged lack of such values among the general population, as well as the failure of political leaders and institutions to implement in practice the formal rights that exist on paper. While extensive civic, political and (sometimes) social rights have been written into successive laws and constitutions (often on universalistic Western models), these are still far from forming the basis for political relationships. Human rights abuses, authoritarian and/or clientalistic political relations, government corruption, judicial impunity, fragmented social organizations, lack of education and economic marginalization are cited as impediments to the civic "foundations" of participatory democracy. This spectrum of impediments to the implementation of formally existing rights evokes laments among both actors and commentators over the lack of a "culture of citizenship". Such arguments, cast in foundationalist terms, have been used both by conservatives to argue against the extension of citizenship rights to a population "unprepared" to handle them, and by progressive intellectuals and community activists as the basis for campaigns in "popular education" aimed at helping people discover their own capacity for political action. In a 1992 public forum entitled Brasileiro: Cidadao?, anthropologist Roberto da Matta expresses such an argument in his analysis of the absence of a "modern and democratic" civic culture in Brazil:

When I imagine the Brazilian citizen, I think of that person made fragile by the absence of social recognition, in that individual without a face, without rights and without resources, located in that interminable wait which is the most perfect symbol, in Brazil, of the absence of a true culture of citizenship [...] A culture which is effectively modern and democratic, in which individual rights are perceived in a radical manner. Radical in the sense that they are effectively contemplated in social practice, and not just in laws. Because no one knows better than us how easy it is to contemplate rights as laws $[. .]^{6}$

In such a situation in which rights on paper do not translate into rights in practice, the question is not who "counts" as a citizen (since even the faceless and resourceless individual cited above is legally a citizen) but rather what kinds of social practices between state and societal actors might make citizenship meaningful. The burden of proof thus shifts from the legal definition to the social relationship, which in turn becomes a question of ethics and political practice, and not just formal entitlements. It becomes, as Roberto da Matta says, a question

"Roberto da Matta, "Um Individuo Sem Rosto", in Brasileiro: Cidadao? (São Paulo, 1992), pp. 1-32. 
of the presence or absence of "social recognition", conceived quite concretely in terms of one's own political participation within variable arenas of social influence. Although it is certainly true that national minorities in Europe are also seeking social recognition, the difference here is the stress on the quality of participation wielded by the citizen, rather than simply on the citizen's access to formal guarantees by the state. Appeals to citizenship have a performative, self-reflexive dimension: simply by entering the public arena and registering a protest or a claim, one is already altering one's civic practices and establishing the grounds for a new form of state/society relationship. The proud assertion "sou cidadao" ("I am a citizen") signals the appeal to human dignity (and to social and self-respect) that follows from the act of participation. Republican appeals to civic virtue are often wedded to the popular narratives of liberation theology: according to this conception of citizenship, in assuming an active and participatory role in the polity, one becomes a "subject" rather than an "object" of history. Or to reexamine the words of Roberto da Matta, the individual (as "citizen") thereby breaks out of the "interminable wait" of a clientalistic and/or authoritarian political tradition, contributing to the implementation "in social practice" of what should already be assured by law.

Citizenship in this normative sense becomes a pathway into the hypothesized "public sphere" of social recognition and influence, through which one can ride on a diversity of vehicles and with a multitude of destinations. Here we see the mobilizing power of the notion of citizenship, as well as its profound social ambiguity. I argue that it is precisely this capacity of the notion of citizenship to give ethical support to a multiplicity of participatory practices that gives it its current dynamism within democratizing countries. In fact, the ambiguity of the language of citizenship - its ability to serve as a universalizing carrier for many particularistic relations and projects - allows it to serve as a sort of "coin of the realm" in the political games of democratic transitions; it is used as a grounding for diverse claims, struggles and alliances as actors battle both for procedural space and substantive influence in state and societal decision-making processes. The fact that Marshall's trio of civil, political and social rights did not develop sequentially over centuries, but were thrown together into the same soup (with a stock of imported ingredients to boot), allows for the inflection of multiple appeals and practices into developing civic identities. This is why in Brazil, for example, we see partially conflicting and/or overlapping appeals to citizenship used to justify such diverse projects as human rights campaigns, strikes and workplace organization, community health councils, child protection laws, industrial training programs, consumer education, sustainable development and, more recently, business/government partnerships and even privatization of state industries.

It is here we must take issue with the presuppositions underlying normative expressions of citizenship and apply a more analytic eye to 
the emerging civic relations and projects that such narratives support. The recent resurgence of concern with citizenship in Latin America should not be seen as a question of idealized democratic foundations, but rather as a complex social and cultural dynamic in need of careful empirical examination. This requires that we shift the epistemological focus away from values and rights as such, and look instead at how social relationships are articulated in particular times and places by means of historically constructed appeals to values and rights. We then see that it is the very ambiguity and multivalence of the notion of citizenship - rather than its universality - that gives it current social dynamism. The importance of the concept of citizenship lies in its capacity to construct social relationships by serving as a carrier for (and bridge between) emergent projects and identities in society. Because of its universalistic and procedural claims, appeals to citizenship can be used by different actors to win public recognition for particularistic and substantive projects of action.

When conceived in this way, conflicts over the meaning of citizenship (and its attending rights and responsibilities) are not simply a question of struggles for cultural control or ideological hegemony, nor are they adequately understood as vehicles for the "legitimation" of particular social actors. Rather, appeals to citizenship play a more intricate role in the structuring of social relationships within changing societies. Such appeals mobilize the discourse of universality to construct historically variable relationships between state, societal and economic actors. They work as bridging mechanisms that can both forge alliances and obscure opposition between differently positioned actors; they allow for the possibility of communication and joint action, as well as set culturally recognizable boundaries upon a field of contention.

Such a reconception enables us to see that despite Da Matta's eloquent lament, countries like Brazil do not, in fact, lack a "democratic culture" (as if this were something preformed and foundational). Rather, they are engaged in a lively process of culture-formation that accompanies - in a dynamic, conflictual and uncertain manner - the process of institutional restructuring of civil society. Instrumental, contingent and ambiguous appeals to citizenship may, by shaping collective learning processes, precede the consolidation of more lasting procedural norms and repertoires of civic participation. Unfortunately (for idealists of civic culture), the inverse is also true: while such norms may indeed support more "active" civic practices and wider access to decision-making processes, they may also, once established, serve to lock in place relationships of political and economic control and/or social exclusion, as regions of leadership are mapped, niches are claimed and new participatory repertoires are routinized. 


\section{RETHINKING CITIZENSHIP: NETWORKS AND PROJECTS}

Given the picture I have sketched of the dynamism and ambiguity of the development of civic culture in democratizing countries, how can we trace and analyze these processes in historical inquiry? Three recent studies of citizenship and civic culture have indicated some promising directions of analysis, although all are limited in regards to my current formulation. Charles Tilly's discussion of the preconditions for democracy and the extension of citizenship rights in European states, ${ }^{7}$ Robert Putnam's study of civic traditions in the northern and southern regions of Italy, ${ }^{8}$ and Margaret Somers' work on citizenship claims in eighteenthcentury England ${ }^{9}$ all offer interactive, regionally variable and historically contingent conceptions of the development of civic culture. All begin to challenge (at least in part) foundationalist accounts by drawing attention to how different ideas about citizenship and/or practices of civic participation develop conjointly with different structures of state and societal relationships. All, moreover, attempt to use recent developments in transactional and/or network analysis to rethink traditional conceptions of civic culture and/or rights.

Charles Tilly offers a useful starting-point in a series of recent articles on democracy, in which he characterizes citizenship in transactional terms as the outcome of historically specific processes of claim-making and bargaining between state and societal actors. He contests idealist and foundationalist views by insisting that the extension of citizenship rights takes different forms in relation to particular histories of struggles, offering an account of English citizenship formation that focuses on entitlements granted by the state in response to popular struggles over mobilization (and taxation) for war. As a contrast with the English case, he discusses the account of democratization in Latin America by Rueschemeyer, Stephens and Stephens, ${ }^{10}$ who claim that citizenship developed as a result of capitalist expansion and the resulting growth of a working class, "who then press for the enlargements of citizens' rights and full inclusion of workers among citizens". ${ }^{11}$ In both cases we see the expansion of citizenship rights as an interaction between two

' Charles Tilly, "Where Do Rights Come From?"' CSSC Working Paper, no. 92 (1990); "Democracy is a Lake", CSSC Working Paper, no. 185 (1994).

Robert Putnam, Making Democracy Work: Civic Traditions in Modern Italy (Princeton, 1993).

' Margaret Somers, "Narrativity, Narrative Identity, and Social Action: Rethinking English Working-Class Formation", Social Science History, 16:4 (1992), pp. 591-630; "Citizenship and the Place of the Public Sphere", American Sociological Review, 58 (1993), pp. 587620; "Rights, Relationality, and Membership: Rethinking the Making and Meaning of Citizenship", Law and Social Inquiry (1994).

${ }^{10}$ Dietrich Rueschemeyer, Evelyne Huber Stephens and John D. Stephens, Capitalist Development and Democracy (Chicago, 1992).

$"$ Tilly, "Democracy is a Lake", p. 15. 
levels of change: large-scale political and economic restructuring, and the practical attempts of conflicting actors to reshape social relationships in the face of those changes. Tilly's dynamic and relational conception of the extension of citizenship rights as a result of particular histories of struggle and claim-making captures an important dimension of struggles over citizenship in Latin America, which are certainly (at least in part) attempts to wrest from a recalcitrant state what Tilly calls the prerequisites of democracy: equality and breadth of citizenship, binding consultation, and protection from arbitrary state action.

Yet in his contractual definition of citizenship as "rights and mutual obligations binding state agents and a category of persons defined exclusively by their legal attachment to the same state", ${ }^{12}$ Tilly too narrowly defines the rights-bearing identity of "citizen" in terms of formal membership in a state. In fact, while Tilly's conception has much to tell us about the state, it has less to tell us about the citizen; citizenship, as the Latin American example demonstrates, is not only a formal legal identity (based in a claim to entitlements), but also an ethical and a practical one. How an actor conceives of him or herself as a "citizen" involves particular self-reflexive conceptualizations of the nature of participation, of the possibilities of social intervention, and of one's relationship (and responsibilities) not only to state, but also to other societal actors. Appeals to citizenship in Latin America are not just about legal claims made on the state (although they are about this too); that is, they are not just about "rights". They are equally about practices, serving as performative exhortations toward the population about different ways of "becoming citizens", which may (according to some conceptions) challenge social actors to overcome the inertia, fatalism, clientalism and messianistic expectation that characterize current political repertoires, and thereby assume a more active role in the polity (although "active", as I have stated, can lead in many different and often conflicting directions, given the variety of social projects in play within so-called "civil society"). As such, appeals to citizenship work in two directions: both toward the state and toward society, thereby serving a transformative role in reshaping political relationships, narratives and repertoires.

Shifting the emphasis from formal rights to cultural norms and relationships in society, Robert Putnam attempts to add a historical and interactive dimension to classical republican theories of "civic virtue". In his recently published book, Making Democracy Work: Civic Traditions in Modern Italy, Putnam discusses a two-decade-long comparative study of the institutional efficacy of decentralized government in different regions of Italy. He concludes that the relatively higher degree of effectiveness in the north, as opposed to the southern regions, can be correlated with the greater density of associational networks in the north and with the

12 Tilly, "Where Do Rights Come From", p. 5. 
predominance of shared civic norms such as trust, cooperation, honesty and solidarity. Such norms and networks, Putnam claims, are more effective predictors of institutional performance than factors such as economic affluence, political polarization, education, urbanism and social or individual stability. Drawing on recent concepts in network analysis, he makes a loosely conceived contrast between the "web-like" (horizontal and cooperative) networks of the north and the "maypolelike" (vertical and clientalistic) networks of the south: "Networks of civic engagement, like neighborhood associations, choral societies, cooperatives, sports clubs, mass-based parties, and the like, represent intense horizontal interactions [...] The denser such networks in a community, the more likely that its citizens will be able to cooperate for mutual benefit [. . . Citizens of civic communities find examples of successful horizontal relationships in their history, while those in less civic regions find, at best, examples of vertical supplication". ${ }^{13}$

Yet despite the advance in conceptualizing civic culture as the historical product of a particular structure of social relations, Putnam ends up in a bind because he continues to see civic culture in idealized and foundationalist terms. In the Parsonian (although he would claim, Tocquevillian) tradition, he presents the "civic virtues" of public-spiritedness, tolerance, trust and solidarity as unproblematic social norms that can be verified as empirically "present" or "absent", rather than as complex and variable cultural constructions. He begins with the ideal of the civic community, and then asks to what degree "social and political life approximate the ideal", ${ }^{14}$ rather than taking the ideal itself as a historically-rooted political narrative that, while it has its own shaping power, also becomes a carrier for particularistic projects of local actors. (As such we have no way of explaining why, in two regions which were both highly "civic" in Putnam's terms, Lombardia supported the conservative Northern League while Emilia Romagna supported the former communists of the PDS.) This idealization is reflected in his reduction of variations in network structure to a dichotomization between horizontal (democratic) and vertical (undemocratic) ties, with the former defined simply by density of participation. This eclipses the multiplicity of forms of communication within and across networks, and especially the bridging function of civic networks (which, as I argue below, is more important than "density" for understanding the development of diverse "projects of citizenship"). Finally, he focuses on civic traditions (rooted in the past) rather than projects of citizenship (directed toward the future), thus getting stuck in what he himself terms the "vicious circle" of cultural determinism; he provides no way of understanding the possibility of future-oriented changes in civic identities and practices, such as those marking the current political landscape in Latin America.

${ }^{13}$ Putnam, Making Democracy Work, pp. 173-174.

14 Ibid., p. 91. 
In a recent series of articles on narrativity, citizenship and the public sphere, Margaret Somers provides a bridge between Tilly's focus on claims and entitlements, and Putnam's stress on civic participation. She addresses some of the problems of Putnam's analysis by treating the Western tradition of citizenship rights not as an empirically verifiable set of social norms, but as an "idealized master narrative" that is contingently appropriated according to different claim-making practices within particular "relational settings". Following the "anti-categorical imperative"15 of relational analysts, she insists that citizenship should not be regarded as a status or an attribute, but rather as "a set of institutionally embedded social practices" constituted by "networks of relationships and political idioms that stress membership and universal rights and duties in a national community". ${ }^{16}$ In this way she addresses some of the ambiguities and contradictions of citizenship theory, namely the conjoining of universalistic discourse with particularistic practices. In showing the differential activation of citizenship rights in the arable and pastoral regions of eighteenth-century England, she illustrates how apparently universal rules regarding membership rights are implemented differently according to particular local patterns of civil organization. Those regions with stronger local cultures of popular participation and struggle (rooted in economic relationships, political-legal institutions, and residential and/or family structures) make more effective claims upon legal rights at a national level. Citizenship "is not in practice exclusively a national and universal institution. Rather, citizenship practices emerge from the articulation of national organizations and universal rules with the particularisms and varying political cultures of local environments (types of civil society)". ${ }^{17}$

Somers' attempt to rethink the foundations of citizenship theory is highly relevant to my current analysis for its stress on the contingent and variable nature of civic practices in relation to particular confluences of narratives, networks and institutional structures. However, her conception of citizenship as a universalizing legal "meta-narrative", contingently activated through local claim-making relationships, takes us only part of the way towards a dynamic conception of the formation of civic culture. By failing to distinguish between narratives of citizenship and the different forms of civic intervention and communication that these support, she loses the ability to understand the contradictory and multivalent nature of civic discourse and practice in democratizing countries. What is missing in Somers' stress on cultural narratives is a more mobile and agentic conception of how such narratives are incorporated into the

\footnotetext{
is See Mustafa Emirbayer and Jeff Goodwin, “Network Analysis, Culture, and the Problem of Agency", American Journal of Sociology, 99 (1994), pp. 1411-1454.

${ }^{16}$ Somers, "Citizenship and the Place of the Public Sphere", p. 589.

17 Ibid.
} 
developing projects of social actors, and how these are communicated and transformed across organizational networks in civil society.

I argue that neither Tilly's "claims", Putnam's "norms", nor Somers' "narratives" sufficiently captures the projective and future-oriented dimension of appeals to citizenship, and the sometimes contradictory role these play in the restructuring of state, societal and economic relationships. To understand the multivalence and social dynamism of appeals to citizenship in the Latin American context, we must develop a set of conceptual tools that make visible both the relational and the projective dimensions of citizen formation in democratizing societies. As such, I propose an approach capable of showing how different narratives of citizenship serve as cultural bridges for emergent social projects, and how such normative understandings shape (and are shaped by) styles of communication, contestation and alliance-formation across changing networks of civic organizations. In the remainder of this paper I attempt to demonstrate the utility of such an approach by analyzing the development of new civic identities and projects among Brazilian youth activists and exploring how these bridge diversified networks of political participation in Brazil.

\section{BRIDGES ACROSS NETWORKS}

As I have noted above, one of the striking characteristics of the 1992 pro-impeachment rallies was their capacity to bring together young people from widely varying personal backgrounds, social networks and political orientations, many of whom had little or no previous experience of political activism. In this sense the rallies were a godsend for the left of center youth militants who did most of the organizing and speechmaking: it allowed them to break out of the tightly-knit activist ghetto and claim a much wider base of support and legitimacy for (in the first place) the student movement as an agent of social intervention, and (secondly, by implication) for their various particularistic projects that were "signed on" in support of the broader "civic" movement for ethics in politics. It was in this crucial sense that, as a prominent news magazine put it, "as students, in addition to studying, they are learning to be citizens". ${ }^{18}$ As self-identified student activists trying to resuscitate a movement across much more complex and diversified social settings than existed three decades earlier, they were able to draw upon the more expansive "civic" identity to provide a bridge between their own preexisting projects, the emergent common political project of "defending democracy", and the diverse and mostly inarticulate projects-information of the young people who were having their first taste of political participation. 
It is here that we must return again to the essential multivalence of the category of citizenship within democratic transitions. In the early period of political liberalization in the late 1970s, the independent labor movement and community groups that mobilized around calls for citizenship rights used such claims to pressure the military regime to ease its repressive policies, allow for increased democratic participation and attend to the needs of the poorer sectors of the population. ${ }^{19}$ The discourse of citizenship was nurtured mainly among the popular movements, the progressive sectors of the Catholic Church, and sectors of the intellectual left; within these circles, demands for state entitlements and calls for popular participation were closely linked. But over the course of the 1980s, as various forms of civil, political and social rights were gradually conceded (although often shakily implemented) and the regime officially passed into civilian (and finally in 1989, democratically elected) hands, the ethical and performative dimension of citizenship gained in salience and spread to other sectors of organized society. In fact the anti-Collor demonstrations, widely hailed as a "defense of democratic institutions", was not directly framed in terms of rights or entitlements at all, but in terms of the ethical qualities of political leaders (although corruption could indirectly be seen as an impediment to the implementation of rights) and in terms of mobilization of "civil society" to express its generalized indignation and demand a change, that is, to act "as citizens". Because the appeal was primarily procedural and ethical (rather than "social" or "economic"), everyone could jump on the bandwagon; "being a citizen" constituted a unifying public identity by which one could defend the political groundrules of democracy as well as guarantee political space for diverse substantive projects.

The youthful celebration of citizenship that appeared during the 1992 rallies must thus be understood in relation to the bridging function it served between actors with different substantive projects for social change. Despite the seemingly "spontaneous" nature of the rallies (a feature much emphasized by more conservative commentators), the youthful manifestations did not spring from nowhere on to the political scene. They rode the crest of a growing public repudiation of the presidency of President Fernando Collor de Mello, following the disclosure of a patronage ring coordinated by his former campaign manager; as such they were part of a wider "Movement for Ethics in Politics", which civil organizations and political leaders had been organizing for months previous to the August rallies. This movement was initially spearheaded by a coalition of professional associations, nongovernmental organizations, religious groups, labor unions, business associations, student associations, and political parties of the center-left; as

19 Gay Seidman, Manufacturing Militance: Workers' Movements in Brazil and South Africa, 1970-1984 (Berkeley, 1994). 
the wave of the public repudiation of Collor grew, even traditionally conservative politicians began to appear in public with their faces painted. The young organizers of the pro-impeachment rallies were embedded within different sectors of these wider networks, giving them a variety of perspectives on the changes in process in the country.

To understand the various forms of youthful participation supported by the emergent discourse of citizenship, it is important to look behind the public euphoria of the street demonstrations and examine the relationships between different networks of activists who collaborated in organizing the 1992 rallies (and who tried to take credit for and give direction to the movement after the fact). The principal organizers included leadership of official student organizations (such as UNE, the National Union of Students, and UBES, the Brazilian Union of Secondary Students) as well as representatives from youth committees of the major political parties (many of whom also serve as directors of national or university-based student organizations). Lindberg Farias, president of UNE at the time of the rallies, was also a militant of the Communist Party of Brazil (PCdoB); present as well were young people from the Workers' Party (PT) which has alternated leadership of UNE with the PCdoB over the past decade; the MR-8, a revolutionary group hidden inside the moderate Party for Democratic Movement (PMDB); the center-left Brazilian Social Democratic Party (PSDB); and the right-wing Party for Progressive Reform (PPR), which had been the old ARENA, party of military dictatorship. This spectrum of partisan orientations already gives an indication of the powerful bridging function of the rallies, in which all of these groups participated "as citizens" with a common goal of ousting Collor (although with a variety of underlying political motives; the country was, at the time, in the midst of campaigns for municipal election, which certainly affected the desire of candidates from all political persuasions to claim the moral highground).

However, more important than their party affiliation per se is the fact that most of these young people represented links with wider networks of youth (and other) organizations, distinguishable by particular structures of ties between groups as well as by particular styles of civic intervention. In Table 1 I have outlined four distinct network structures that I have found in my research among youth organizations in São Paulo. The salient distinguishing factors are not ideologies or political platforms, but rather the different structures of relationships within and between groups, and the cultural narratives by which such relationships are communicated and sustained. The different participatory cultures within such networks cannot be captured by a simple dichotomization between "vertical" vs. "horizontal" structures, as Putnam sketches it, or by linking "civic norms" to density of network ties. Much more important are the particular styles and pathways of communication within and between networks, the manner in which their members construct 
Table 1. Networks of youth organizations

\begin{tabular}{|c|c|c|}
\hline Network structure & Characteristics & Examples \\
\hline $\begin{array}{l}\text { A) "Political } \\
\text { cadres" }\end{array}$ & $\begin{array}{l}\text { A constricted and centralized } \\
\text { structure based in control of } \\
\text { student organizations, in which } \\
\text { activists are expected to } \\
\text { "detonate" social frustrations } \\
\text { and mobilize full-time } \\
\text { commitment among militantes } \\
\text { for projects of revolutionary } \\
\text { change. }\end{array}$ & $\begin{array}{l}\text { "Classic" Marxist-Leninist left } \\
\text { (PCdoB, MR-8) whose youth } \\
\text { militancy (UJS) has control of } \\
\text { major student organizations: } \\
\text { UNE, UBES, UMES, as well } \\
\text { as gremios and centros } \\
\text { academicos in schools and } \\
\text { universities. }\end{array}$ \\
\hline $\begin{array}{l}\text { B) "Grass roots } \\
\text { movements" }\end{array}$ & $\begin{array}{l}\text { A widely-based structure with } \\
\text { dense, overlapping ties in } \\
\text { multiple social movements, in } \\
\text { which militants engage in } \\
\text { projects of popular } \\
\text { "conscientization" to inspire } \\
\text { participation in grass roots } \\
\text { struggles for social justice and } \\
\text { political transformation. }\end{array}$ & $\begin{array}{l}\text { Newer "democratic socialist" } \\
\text { left, led especially by the PT } \\
\text { (Worker's Party), CUT/labor } \\
\text { unions, the CEBs and youth } \\
\text { pastoral of the Catholic } \\
\text { Church, and urban/rural social } \\
\text { movements. }\end{array}$ \\
\hline $\begin{array}{l}\text { C) "Civil } \\
\text { institutions" }\end{array}$ & $\begin{array}{l}\text { A decentralized, and sprawling } \\
\text { structure of civic associations, } \\
\text { emphasizing autonomy, } \\
\text { partnership and social } \\
\text { responsibility as expressed } \\
\text { through projects of "opinion } \\
\text { formation", policy influence } \\
\text { and institutional change. }\end{array}$ & $\begin{array}{l}\text { Non-governmental } \\
\text { organizations, youth } \\
\text { committees of PSDB (Social } \\
\text { Democrats); professional } \\
\text { associations; civic campaigns } \\
\text { against hunger and violence; } \\
\text { Junior Businesses; AIESEC; } \\
\text { modem business leaders. }\end{array}$ \\
\hline $\begin{array}{l}\text { D) "Technical } \\
\text { experts" }\end{array}$ & $\begin{array}{l}\text { A tightly connected yet } \\
\text { dispersed structure of political } \\
\text { and economic collaboration, in } \\
\text { which technical assistance is } \\
\text { offered to politicians by young } \\
\text { professionals whose influence } \\
\text { "percolates" independently } \\
\text { through society in support of } \\
\text { particularistic projects. }\end{array}$ & $\begin{array}{l}\text { Conservative students in } \\
\text { business/university nucleus, } \\
\text { based in Faculty of Mackensie; } \\
\text { links to PPR (former PDS/ } \\
\text { ARENA); major business } \\
\text { federations (FIESP, CNI, } \\
\text { etc.). }\end{array}$ \\
\hline
\end{tabular}

ties (i.e. alliances and disputes) with other organizations, and their strategies for influence in the wider society.

Each network structure as described above is characterized not only by a particular patterns of links between organizations, but also by a distinct theory and practice of how social intervention works. Organizations within networks share (albeit roughly, depending on their positions of connection and influence) certain mobilizing narratives, which provide practical guidelines on how social influence works, how people are moved to participate, how groups communicate, how social change happens. 
These in turn support (and are supported by) different conceptions of citizenship, defined here as self-reflexive political narratives that draw upon universalistic principles to shape practices of intervention in the public arena, in ways that (implicitly or explicitly) facilitate the realization of their substantive projects. Such narratives inform the particular ways in which the organizations within each network structure organize their political struggles and alliances, as well as their practical understanding of what it means to "be a citizen".

\section{NETWORK STRUCTURE A: "POLITICAL CADRES"}

Within network structure A (which I refer to here as that of "political cadres"), the language of citizenship has been a recent acquisition, wedded uneasily to the classical revolutionary discourse of the "old" left, which, as I have noted above, has traditionally been skeptical of the formal equality of citizenship rights and its links to bourgeois democracy. The structure of this network is exemplified by the highly centralized, restricted party organizations of the PCdoB (Communist Party of Brazil), ${ }^{20}$ a small but persistently visible party that emerged from its clandestine status in the early 1980 s, and until recently defended Albania as the model socialist republic. The PCdoB is organized according to the Marxist-Leninist model of democratic centralism, in which debates are carried on inside the party and a unified front presented at all times to the public; it has an onion-like structure in that it operates through layers of slightly more inclusive organizations (such as UJS, the Union of Socialist Students), as well as highly visible public leadership of major "non-partisan" organizations such as UNE (which students from the PCdoB have controlled steadily for the past three years, alternating control with the PT during the previous ten). It seeks wider social influence through the placement of its limited "cadres" of militants in satellite organizations in schools and universities, from which they can work at face-to-face persuasion and recruitment.

The idioms used to describe the strategies of social influence within this network structure assume that revolutionary consciousness in the form of social frustration and critique is already present, only needing to be "detonated" (or alternatively, "activated" or "galvanized") by the political leadership (which is accordingly spread strategically out in the population) in order to set in motion a transformative and/or revolutionary social movement. As a young leader of the PCdoB (who is also a director of UNE) told me in an interview, "We of the UJS never stopped believing that the student union has the character of detonator,

20 The MR-8, which I do not describe here, also exemplifies this basic structural pattern and has similar narratives of social influence, although young people in this group tend to discuss citizenship in slightly more militantly nationalistic terms. 
of denunciation, of a thermometer of the social process". The discourse of citizenship and rights fits uncomfortably within this structure, where the emphasis on entitlements and/or on social dialogue end up seeming like social-democratic half measures. Still, such appeals are recently entering into the discourse of young militants as they try to reach out to young people whose concerns are less immediately revolutionary. This ambivalence can be seen in the attempt of the president of UJS (also a militant of the PCdoB) to qualify the struggle for citizenship rights with that of a wider social transformation:

UJS proposes to be a group that mobilizes young people in defense of their rights, to education, to work, to sports, to space for cultural production, rights that today are diminishing more and more. But beyond helping students defend their rights, UJS also defends the opinion that Brazilian society needs a more radical alteration in its organization. The principal problem of Brazilian society is that we live in a capitalist society, and that we need to construct another alternative for developing the country. That's why we chose to call this group the union of youth - in the struggle for the defense of the rights of youth but also in the struggle for another system, for socialism. (interview, Jorge Panzera)

Despite such persistent attempts to wed the newer language of rights with the classical project of socialist transformation, the need for a language able to bridge social distances became paramount during the 1992 demonstrations. Given the sudden prominence of UNE as the "representative" of such wide and diversified sectors of young protestors, the revolutionary discourse (including references to class struggle) nearly disappeared from the speeches of Lindberg Farias, its attractive young president, and other leaders of the PCdoB. Instead, Lindberg emphasized the independent, nonpartisan and "civic" nature of UNE as a representative of "all of the students", distinguishing his position as president of UNE from that of a militant of the Communist party. Reinforcing this broader profile, the charming and photogenic Lindberg Farias became a pop hero in the media; by using a more inclusive vocabulary and youthful conversational style he helped to break down the image of the grim, bearded militant. It was not, therefore, as "revolutionaries", or even precisely as "students" that UNE claimed (in the name of students) the right to social protest and influence, but rather, as we have seen, as "citizens":

People forget, at times, that in addition to being students, we are citizens. So that beyond the problems of the classroom, we also have the right to be worried about and interested in the major questions of the country. Our position is one of independence. We are there to applaud and approve the government in its progressive aspects, and at the same time to hiss, shout, protest, go to the streets when what it does is wrong. But this question of participating and influencing in the more general questions, we won't give this up. It is part of the historical tradition of our organization. (interview, Lindberg Farias) 
Because of the necessity of establishing relationships with a highly diversified youth population, the more expansive language of citizenship has also accompanied a more pragmatic and flexible strategy of alliancebuilding with different political groups. These practices were reinforced by the experience of militants of the PCdoB in organizing the anti-Collor rallies together with youth from other organizations, particularly those in network structure C (below), who already had a strongly developed narrative of civic participation. In the past few years since the rallies, UNE has lost some of its prominence in the press (which has in fact published a number of critical surveys characterizing the organization as sectarian and unrepresentative of the wider student population). The challenge for the youth of the $\mathrm{PCdoB}$ is to continue to capitalize on the bridges they were able to build during the 1992 rallies, without losing their underlying project of constructing a socialist society. Toward these ends they are painfully reexamining (internally, according to democratic centralism) their own conceptions of socialism as well as strategically expanding the bridging language of democratic citizenship.

\section{NETWORK STRUCTURE B; "GRASS ROOTS MOVEMENTS"}

Ironically, the strongest opposition to the Communist youth within the student movement comes not from conservative groups, but rather from those most close to them ideologically, the young people in network structure B ("grass roots movements"), roughly designated as the "new" or "democratic" left. These young people reject the "vanguardist" practices of the PCdoB and UJS and rather stress more "democratic" processes of popular participation and grass roots organization as an alternative path for the construction of socialism. The close-knit, overlapping and regionalized structure of militancy - in which young people may simultaneously be militants in local nucleos and diretorios of the PT (Worker's Party), in the Catholic youth pastoral, in education, housing, health or other neighborhood movements, in labor unions, and/ or in student organizations in the school or university - results in dense, ingrown networks of relationships and intensive styles of political participation. Being a militant is for young people within such networks a full-time, personally and morally absorbing activity; as one young leader in the PJMP (Youth Pastoral for Popular Movements) told me, "at times we are so much involved in the militancy that we forget our lives, work, family, school".

The tendency toward dense internal ties is reinforced by the narratives of citizenship and social influence within these networks, which focus on intensive processes of "conscientization" and "popular education", which (at least as theoretically elaborated by Paulo Freire, Carlos Rod- 
riques Brandao, and liberation theologists ${ }^{21}$ ) require a long-term process of social dialogue and critical reflection on social reality (always in group contexts) in order to gain a transformative perspective on one's own social practice. This focus on the becoming a "subject of history" (according to the methodology of "see, judge, act" formulated by the Catholic youth pastoral) is different from the concept of "detonating" a revolutionary process; the emphasis switches to a gradual change in political culture by which people begin to demand their rights and fight for social justice in a variety of social forums. The following quote from a priest who serves as an advisor for PJMP (a more radical branch of the Catholic youth pastoral that works specifically with militants in community social movements, unions and political parties) demonstrates the manner in which social empowerment is articulated together with "rights" and other forms of participation in so-called "intermediate organizations":

PJMP emerged as a youth pastoral of impoverished youth, of the exploited, of workers, of poor youth. It is not a pastoral for poor youth. It is formed by them, the protagonism is theirs. Poor youth need a space which is theirs, in which they take consciousness and assume their class [. . . ] and in this identification with class, they go on to the intermediate organizations - parties, unions, associations - to defend their rights [...] (interview, Alberto Panichella)

As this statement indicates, it is within these grass roots networks that narratives of citizenship first began to be wedded with class-based claims on the state, emerging from labor activism and community organization in the late 1970s and early 1980s. At that time, as Gay Seidman tells us, "Citizenship - redefined to include political participation, labor rights and entitlements to state services - became a code for challenging the exclusion of most Brazilians from the benefits of capitalist development".2 The PT continued to soften its initial class discourse and broaden its appeals to citizenship over the course of the 1980s as the party saw the necessity of appealing to middle-class voters (and growing white-collar unions), as well as the need to incorporate a heterogeneous collection of social movements in its projects for social transformation. ${ }^{23}$ In both cases citizenship appeals performed a bridging function that allowed the party to extend its reach beyond those sectors of the population traditionally designated as "workers". This bridging was performed by closely welding the language of citizenship to that of the

${ }^{21}$ See Paulo Freire, Pedagogy of the Oppressed (New York, 1968); Carlos Rodrigues Brandao (ed.), A Questao Politica de Educacao Popular (São Paulo, 1980); Daniel Levine, Popular Voices in Latin American Catholicism (Princeton, 1992).

2 Seidman, Manufacturing Militance, p. 227.

23 See Margaret Keck, The Workers' Party and Democratization in Brazil (New Haven, 1992). 
struggle of marginalized groups (the poor, workers, blacks, women, indigenous peoples) for political and economic inclusion. In this way the "formation of citizenship" could become a more expansive and universalistic frame for community, labor, racial/ethnic, feminist, and other forums for popular empowerment and contestation. It also became a pathway from social movement agitation to more institutionalized forms of political participation, such as electoral politics, labor and community federations, and non-governmental organizations.

Yet like the more orthodox leftists, many young people in network structure $B$ tend to be ambivalent about the discourse of citizenship, which is often bemoaned among the more steadfastly "radical" militants in this network (those with closest ties to the classical left) as being a poor substitute for class. An ongoing internal debate in the PT centers around to what degree the party is relinquishing its class roots and adopting accommodationist policies by entering into "institutional paths" or, in contrast, to what degree the changes in the political situation in Brazil and in the world require a greater openness to political alliances and a commitment to participate in the democratic process. Echoes of this debate can be heard in the following affirmation of the idea of citizenship voiced by a young leader in the secondary school movement (also a militant of the moderate branch of the PT), who reinforces both the idea of organization of the "bases" and the opposition to the co-optative practices of the traditional left:

We have to begin with grass roots movements. [Youth organizations] of PT do not try to coopt a person for the PT, but rather to talk to that person about democracy, about the rights that he has, so that the person begins to exercise citizenship. This is a word that I and the majority of the people in the PT are assuming. The word today is not capitalism, is not socialism, is not neo-liberalism [. . . It is citizenship. We have to guarantee citizenship for the Brazilian people. And from there we will win advances in diverse areas [. . . Citizenship means rights, together with the responsibilities of the citizen in relation to society [. . . ] We have to convince people to demand their rights, and to exercise their responsibilities. From there we see the organization of society. (interview, Ricardo Jesus de Santana)

Despite such defenses of democratic procedures, in recent years ability (or willingness) of youth militants within such groups to dialogue and/ or make alliances with young people from other social networks has been minimal. The intense, close-knit and regionalized structure of the militancy tends to counteract the kinds of broader appeals and practical alliance-building that the PCdoB is currently engaged in. Often young people are so deeply involved in organizing their various grass roots militancies, spread out in various social "bases", that they lack the centralism and strategic focus that has allowed the PCdoB to maintain control over UNE and other student organizations. They tend to be intensely concerned with the political dramas within their own local 
networks (such as internal disputes of "tendencies" within the PT) and much less with building non-partisan organizations, such as UNE, or engaging in co-sponsored activities with other civic organizations, such as those that fall under what I call network structure C ("civic institutions"). Although militants from the PT are the second political force in UNE, and have control of student organizations in several major São Paulo universities, including the University of São Paulo, they have gained a reputation for sectarianism and refusal to dialogue, and are frequently accused of considering themselves donos da verdade (owners of the truth) by other youth activists. Such sectarianism ironically resulted in the near absence of salient leadership from the PT in the organization of the 1992 pro-impeachment rallies, despite the strong presence at the marches of young people who consider themselves militants and/or sympathizers with the party. What is important here is that this restricted political practice and tendency toward ghettoization is reflected both in the network structure (dense, bounded and overlapping ties) and in the particular narratives of citizenship and social intervention that permeate the networks.

\section{NETWORK STRUCTURE C: "CIVIC INSTITUTIONS"}

The third network structure, in contrast, is one that takes expanded social dialogue within "civil society" as its philosophical and organizational core. This makes for a much more sprawling and chaotic set of relationships, constructed on the basis of many loose and often ambiguous ties between groups. Such networks are characterized by many autonomous (or semi-autonomous) centers of organization scattered throughout different political, economic and institutional sectors of society. Professional associations (such as those of lawyers, doctors, educators and scientists), non-governmental organizations (environmental, human rights and social service groups), research institutes and, more recently, business associations play an important role in these networks. Political sympathies among youth in these networks range from professions of non-partisanship, to explicit sympathy with the PSDB or more moderate sectors of the PT, to active militancy in committees of political parties of the center-left, which are spread through various campaign headquarters and university nucleos.

Because of the more dispersed and permeable structure of these networks, young people who become involved in different forms of participation do not generally fall into the same all-consuming patterns of militancy as in network structures A or B; nor is the moral charge of personal/political transformation quite as strong. Young activists in the PSDB, for example, describe themselves as "opinion-formers", reflecting a more individualist "multiplier" theory of social influence, which finds practical realization in the open and diversified network 
structure. Such a conception (and less bounded set of relations) allows political participation to accompany the personal pursuit of a variety of developing careers and life projects. Reflecting the more privileged socio-economic position of most participants in the network, citizenship is often conceived not in terms of entitlements, but in terms of "mutual responsibility" and pursuit of the "collective good", as well as a sort of cultural noblesse oblige, as indicated by the following quote from an interview with one of the coordinators of the youth committee for a senator from the PSDB:

Citizenship is when you understand that if you live in a society, then that society signifies mutual responsibilities, as if you were members. Citizenship is you understanding that you have rights within the group in which you live, and obligations. In a country like ours where there exist illiterates in massive quantities, with people who don't have access to culture, being a citizen also means that if you have culture, that you should bring this consciousness to people. It means wanting society to develop as a whole, for the collective good, and not for private good. Citizenship is fighting not for what is good for me, but what is good for my society. (interview, Fernando Guimaraes)

An important element in such narratives of citizenship is that "membership" signifies both rights and responsibilities, which include the responsibility to look out, in the context of an unjust society, for the welfare of those that have less (note the difference from the basismo of the previous quote, where the poor themselves are declared the protagonists). Again, the appeal is not simply to entitlements from the state, but to one's relationship with other "members" of society (i.e. citizens are not only those who make claims, but also those who respond to the needs and/or claims of others). The recent "Citizen Campaign Against Misery" that emerged in the past three years, which sets up local citizen action programs to gather and redistribute food to the poorer population (linking social movements, social assistance programs, NGOs, businesses and government agencies) is a vivid example of this philosophy, as is the "Citizenship Program" set up by students at USP law school to conduct literacy, legal advocacy and consumer education programs in slum areas or favelas.

Not surprisingly, given the legal dimensions of citizenship, legal associations (and recently, law students) have played an important articulating role in this network; the 1992 pro-impeachment rallies, for example, were co-sponsored (with UNE) by the OAB (Brazilian Order of Lawyers), which was one of the major instigators of the "Movement for Ethics in Politics". Despite its semi-corporativist structure, the OAB was also a vital actor in the defense of human rights at the end of the dictatorship, as well as in discussions of formal citizenship rights and the elaboration of the 1988 constitution. Linked to (although autonomous from) the OAB is the centro academico of the Law School of the University of São Paulo, with roots going back to student movement at 
the beginning of the century. In 1992 its president, Marco Aurelio Chagas Martonelli (who sympathizes, but is not affiliated with the PSDB), was an important organizer of the pro-impeachment rallies (one of which ended up in the patio of the law school). Marco Aurelio's conception of citizenship clearly stresses participation as a critical component of a civic community:

Citizenship is participation in society. In a phrase, that's what it is. For me citizenship is participation differentiated on all its levels. It is not raw participation, but participation with the objective of community co-existence. Depending on what you are doing, you are preserving communities, big or small. Private or not. If you are participating in your community neighborhood, or your community in a favela, you are exercising citizenship, globally, but directed toward your nucleus. If you are participating in Amnesty International, you are working as a citizen, but on another level of your reality. Both are important [...] People have to think about their citizenship even for egoism, to see their world improve. (interview, Marco Aurelio Chagas Martonelli)

This last appeal to "citizenship for egoism", while slightly different from the magnanimous "common good" narrative above, demonstrates an explicit way in which universalistic narratives can serve as carriers for particularistic projects. Such links between personal and collective interests play a growing role within this network structure, especially within sectors that are closer to the business community. Recently appeals to citizenship from certain younger and more "modern" business leaders have gained increasing prominence as well as institutional backing; such leaders recently formed a group called the PNBE (National Thought of Business Bases), an opposition group within the more conservative FIESP (Federation of Industry of São Paulo). Many of these younger leaders write regular opinion articles in major newspapers and make frequent talk show appearances; some even campaigned for Lula, the candidate of the PT, in the 1994 election (although most probably supported Fernando Enrique Cardoso of the PSDB). They talk about "civic responsibility", defend "sustainable development" and government/ business "partnerships", and see a robust civil society as essential to establishing a stable environment for investment and marketing. The PNBE (allied with UNE and the OAB) was also a central sponsor of the "Movement for Ethics in Politics" that led to the 1992 rallies.

Youth organizations linked formally or by inclination to these modern business sectors are growing, especially among students in economics, administration, and management. Examples can be found among the Junior Businesses that are mushrooming on various college campuses, which offer consulting services by students to small businesses and (sometimes) social programs, and which see themselves as "organizations of civil society". Another highly interesting example is AISEC (International Association of Students in Economics and Management), an international student network that has a vibrant chapter in São Paulo, 
which recently sponsored a conference on "Business Citizenship" at which about 400 students from various universities participated. AISEC takes very seriously the task of educating future business leaders for "social responsibility" - conceived in terms of business ethics as well as environmental and social problems - and sees itself as a link between businesses, universities and non-governmental organizations. As the following quote from one of the directors of AISEC indicates, the group takes a proactive, solution-finding approach to citizenship, explicitly rejecting participation based primarily on criticism (or as the leader of the PCdoB said, in a more favorable tone, "denunciation"):

[A citizen] is that person that sees that she is part of society. So that whatever she does, it is going to effect the society as well. If she tries to do something begins with her, something to improve the situation, then she is contributing to society. It means consciousness that the person, the business, the organization, can do something. It means not just to criticize; or rather, to criticize in a productive manner. To criticize while presenting solutions. Because generally, we say, oh the government, the business, does this and that, but we only criticize. That puts the person in a passive position. No, criticize, but also propose solutions, and act. (interview, Katia Yokoyama)

Because civic projects framed in terms of partnership, dialogue and social responsibility are so strong within this network, there is considerably more possibility for communication and alliance-building both within and across the network. Youth from the PSDB, for example, have a much easier time collaborating with students from the PCdoB in the leadership of UNE (even entering at times into joint directorships) than do the youth of the PT, despite a greater ideological distance. As I have noted, the participation of youth from the PSDB in the organization of the 1992 rallies helped push the PCdoB toward a more inclusive civic language. Many organizations within this network structure (including the law student association, AISEC and the Junior Businesses) achieve this alliance-building capacity by playing up the non-partisan or "autonomous" nature of the organizations and stressing their "civic" dimension; here again projects framed in terms of citizenship serve a bridging function. On the other hand, because of the sprawling and decentralized network structure, there is often less than complete communication between groups, the tendency to duplicate (in autonomous fashion) the work of others, as well as competitive struggles to find and control particular niches of social influence (or paths toward political careers). For example, I found at least three or four different groups in the PSDB trying to present themselves as the "youth of the PSDB" during the electoral campaign, some linked to the party bureaucracy, some to various campaign headquarters, some to nucleos in universities. This same semi-competitive pattern can be seen in the Junior Businesses as they spread through different universities, although they are trying to 
The Formation of Citizenship Across Youth Networks in Brazil 155

institutionalize and control this proliferation through the formation of a state federation.

\section{NETWORK STRUCTURE D: “TECHNICAL EXPERTS”}

The final network structure that I examine here (which I call "technical experts") also tries, like some of the organizations described above, to construct bridges between students and businesses, but with a much different conception of citizenship (serving as a carrier for a different set of substantive projects). This relatively close-knit (yet sectorially dispersed) network structure is composed primarily of self-designated "conservative" students in a variety of professional areas (engineering, medicine, biology, law, administration, etc.), who began meeting in the mid-1980s to discuss the connections between the education they were receiving in the universities and the needs and realities of business firms, primarily the major industries linked to FIESP. The core group of this network was (and remains) based in the Faculty of Mackensie, a traditionally conservative university; one of their principal articulators, Flavio Comte, was president of the centro academico of the engineering department. Several years ago the group was discovered by Paulo Maluf, a populist conservative and perennial candidate for mayor, governor and president, who finally won the São Paulo mayoral election against Luiza Erundina of the PT in 1992. During the recent campaign Maluf asked Flavio Comte and other youth leaders to help to organize the youth of his party, the PPR (formally PDS and ARENA, party of the military regime). The link was now threefold: university, business, politicians. According to Flavio, the goal of the student group is to serve as a highly trained body of professionals in various areas of expertise, to which politicians of the PPR can turn for technical advice on carrying out specific political and/or social projects; the youth provide "honest cost/benefit analyses" on anything from constructing roadways to building sewage systems or opening hospitals.

While citizenship is not a term that emerges as spontaneously in the projects of these students as it does for those in network structure $C$, these young people also have a distinct theory and practice of social influence that they can link, when pressed, to a particular conception of citizenship. For example, in contrast to the youth from the networks examined above, they are not interested in "detonating" mass movements, developing "critical consciousness", or even precisely "forming opinion". Rather they insist that people already know what they want; the job of the politician is simply (in populist fashion) to give it to them. The potential influence of the students comes through their technical influence in solving practical problems that people have in their daily lives. This form of influence is reflected in the network structure: because these students are spread throughout society, acting primarily 
in their own individual spheres of expertise (e.g. universities, business firms, professional associations), their influence is described as "percolating" through the society. In Flavio Comte's words, "it passes so rapidly and so deeply that no one perceives it until everyone is playing the same game". This is opposed to the "arrogance" of the left in supposing that activists know better than the people themselves what the people want, and "imposing" their view from the outside. Underlying this theorization of social influence is a classically liberal conception of citizenship that places emphasis on the freedom of the individual to do what is in his or her own best interest, and the obligation of the government to protect this freedom:

Citizenship, in my opinion, is nothing more than that you guarantee that individual wills are complied with. If today's society, young or old, wants to be individualist, to have its individual interests attended before collective interests, I believe that it is the obligation of you, who are in power, in command, within parameters which are absolutely reasonable and normal, without exaggerations from either side, to make this possible. Because the governor, when he is elected democratically, is nothing more than an executor of the will of the collective. The governor has little right to "think" anything. He has to present a proposal, give a personal opinion, but he has much more to respect the will of those who elected him than his own. This would be the ideal politician. (interview, Flavio Comte)

According to this conception, citizenship does not consist of state entitlements, but rather is realized by a certain minimalist role of the state - which preferably farms out public services to private profit-making firms, who will supposedly carry them out much more efficiently. Nor is it characterized by "popular participation"; such politicians seek to demobilize social movements through clientalistic and populist projects that solve local problems without involving the population in their resolution. Flavio Comte, for example, described a trip in which he took students from the Mackensie group to a favela, and solved a water contamination problem by lifting a hose out of the water (incidentally, it is interesting how importantly "trips to favelas" figure - although with very different implications - in the civic practices of all four network structures). Citizenship comes not from any obligation of the state to citizens, nor from mutual obligations between citizens, but rather from the capacity of citizens to exercise "free arbitration" in their private lives, where freedom is conceived primarily in terms of economic independence:

If I give a salary to you every month, you can exercise your free arbitration. You can choose who to vote for, where you are going to live, where you will work, how many children you have, what religion you are going to follow. You are free to exercise your citizenship. But if I give you day care, school, hospital, food, house, security, and I don't give you a salary, you are going to have to do exactly what I want you to do. Because if not I take everything away and 
you don't have anything. With a salary, no. Because salary is sacred. You deliver it at the end of the month, and you turn your back. You could even be feeding someone who is going to destroy you. But that's the game of life. This is true democracy. (interview, Flavio Comte)

One difference between young people in this network structure and those in the others is the proximity to political and economic power. Flavio Comte, for example, explicitly described his position as a "bridge" between different sources of influence: he has access to important political leaders, to university presidents, and to "captains of industry". Along with other young people from the youth committee of the PPR, he is currently employed by the city government, where he supervises one of Maluf's public works programs. With such high stakes, he takes a rather scornful view of the disputes for power in the student movement; although he attends the congresses of UNE in order to know what is going on, he has never tried to gain a leadership position in the organization (although his group has maintained their historical control of the student association at the Faculty of Mackensie). He does, however, claim that the particular "philosophy" of his group allows it to communicate more quickly and convincingly with the general student population than the more ghettoized students of the left. Despite the tendency to keep the student movement at arms length, youth within this network do make occasional pragmatic alliances with ideologically divergent groups; for example, they joined forces (and provided logistical support) for the caras pintadas during the 1992 rallies. Flavio describes how surprised the press was to see him riding "arm and arm" with Lindberg Farias of the PCdoB. An important factor in this apparent display of civic non-partisanship was the fact that Maluf was at the time heading into the final swing of his campaign for mayor; as coordinator of the youth committee of the PPR, Flavio had to mark his presence in the generalized bridge-making that characterized the enthusiastic "demonstration of citizenship".

\section{CONCLUSIONS}

By studying such wide variations in appeals to citizenship across different networks of youth activists involved in the 1992 rallies, I hope to contribute both to a historical understanding of youthful participation in the Brazilian transition, and to a more dynamic theoretical conception of citizen-formation in democratizing countries. I argue that we must move beyond idealist and/or formalistic conceptions of citizenship and civic culture, toward a view of citizenship as a historically contingent, interactive vehicle of articulation, conflict and dialogue. Such a conception takes into account (1) the multiplicity of appeals to citizenship coming from diverse and conflicting social sectors; and (2) the potential dynamism of such appeals in reshaping relationships between statè, 
societal and economic actors. In focusing on the multivalence, relationality, and projective force of the discourse of citizenship, I show how it functions simultaneously as a claim to rights, a call for participation and a carrier for a competing social projects. It is within such highly mobile and politicized fields of shifting meanings and relationships that young people carry out the difficult work of "learning to be citizens". 